\title{
Separation and Recovery of Gold(III), Palladium(II) and Platinum(IV) by Solvent Extraction Using a New $\beta$-Diketone Derivative from Acidic Solutions
}

\author{
Elzbieta Radzyminska-Lenarcik ${ }^{1, *(\mathbb{D})}$, Ilona Pyszka ${ }^{1}(\mathbb{D})$ and Artur Kosciuszko ${ }^{2}$ \\ 1 Faculty of Chemical Technology and Engineering, UTP University of Science and Technology, Seminaryjna 3, \\ 85-326 Bydgoszcz, Poland; Ilona.Pyszka@utp.edu.pl \\ 2 Faculty of Mechanical Engineering, UTP University of Science and Technology, Al. Prof. S. Kaliskiego 7, \\ 85-796 Bydgoszcz, Poland; artkos@utp.edu.pl \\ * Correspondence: elaradz@utp.edu.pl; Tel.: +48-52-374-9065
}

check for updates

Citation: Radzyminska-Lenarcik, E.; Pyszka, I.; Kosciuszko, A. Separation and Recovery of Gold(III),

Palladium(II) and Platinum(IV) by Solvent Extraction Using a New $\beta$-Diketone Derivative from Acidic Solutions. Materials 2021, 14, 4436. https://doi.org/10.3390/ma14164436

Academic Editor:

Karolina Wieszczycka

Received: 8 July 2021

Accepted: 6 August 2021

Published: 8 August 2021

Publisher's Note: MDPI stays neutral with regard to jurisdictional claims in published maps and institutional affiliations.

Copyright: (c) 2021 by the authors. Licensee MDPI, Basel, Switzerland. This article is an open access article distributed under the terms and conditions of the Creative Commons Attribution (CC BY) license (https:/ / creativecommons.org/licenses/by/ $4.0 /)$.

\begin{abstract}
This study indicates that a new amine derivative of $\beta$-diketone (EDAB-acac) can be successfully used in an acidic medium $(\mathrm{HCl})$ to separate a mixture containing $\mathrm{Au}(\mathrm{III}), \mathrm{Pd}(\mathrm{II})$, and $\mathrm{Pt}(\mathrm{IV})$ ions using solvent extraction. The study was conducted in single and ternary model solutions. The impact of acid concentration and the type of solvent (toluene, chloroform, methylene chloride, 2-ethylhexanol) on separation efficiency was discussed. It has been shown that increasing the $\mathrm{HCl}$ concentration in the aqueous phase does not favor extraction. In contrast, solvents with high donor numbers (methylene chloride, 2-ethylhexanol) increase both the extraction percentage of $\mathrm{Pd}$ and $\mathrm{Au}$ as well as the separation coefficients of Pd in relation to Au and Pt. The palladium(II) and gold(III) (which form 4-coordinated planar $\left[\mathrm{MCl}_{4}\right]^{2-}$ complexes) are extracted most efficiently, $\mathrm{Pd}(\mathrm{II})(87-93 \%)$ and $\mathrm{Au}(\mathrm{III})(56-62 \%)$. The stripping of $\mathrm{Au}(\mathrm{III}), \mathrm{Pd}(\mathrm{II})$, and $\mathrm{Pt}(\mathrm{IV})$ ions from the EDAB-acac-methylene chloride phase was also investigated using $0.5 \mathrm{M}$ ammonia aq., mineral acid ( $5 \mathrm{M} \mathrm{HCl}, 5 \mathrm{M} \mathrm{HNO}_{3}$ ), $0.1 \mathrm{M}$ thiourea in $\mathrm{HCl}$ and $0.5 \mathrm{M}$ ammonium thiocyanate. A 3-step stripping process was proposed for the recovery of $\mathrm{Pd}(\mathrm{II}), \mathrm{Au}(\mathrm{III})$, and $\mathrm{Pt}(\mathrm{IV})$ from the Pd-Au-Pt mixture in the EDAB-acac-methylene chloride system. In the first stage, the aqueous phase is treated with $5 \mathrm{M} \mathrm{HNO}_{3}$ (Pt separation), followed by the application of $0.5 \mathrm{M}$ ammonia ( $\mathrm{Pd}$ separation) and, finally, $0.1 \mathrm{M}$ thiourea in $\mathrm{HCl}$ (Au separation). The solvent extraction with EDAB-acac in acidic medium $(\mathrm{HCl})$ can be used for separation of $\mathrm{Pd}(\mathrm{II})$ and $\mathrm{Au}(\mathrm{III})$ ions from e-waste leach solutions.
\end{abstract}

Keywords: solvent extraction; e-waste; precious metal separation; palladium; platinum; gold

\section{Introduction}

Electrical and electronic equipment has become ubiquitous and the consumption of such goods is increasing every year. The growing demand is accompanied by the increase in the flow of electro-waste (e-waste), which is among the fastest-growing ones in the world [1,2]. According to the latest UN report, in 2019, the world generated about 53.6 million $\mathrm{t}$ of electronic waste, with $7.3 \mathrm{~kg}$ per capita.

The increasing demand for precious metals is driven by the growing development of advanced technology and electronics. Precious metals are considered strategic metals due to their unique properties and lack of possibility to substitute. Since platinum metals (e.g., Pd, $\mathrm{Pt}$ ) are among the rarest elements in nature and because of the depleting resources of gold deposits, the process of producing pure precious metals is expensive and technologically difficult. It is, therefore, necessary to recover them both from industrial waste and used products. The high price of platinum $(\$ 1203 / \mathrm{oz})$, palladium $(\$ 2785 / \mathrm{oz})$ and gold $(\$ 175 / \mathrm{oz})$ on the market (BASF Catalysts-Metal Prices) [3] further encourages the search for new ways to recover these metals from industrial waste (e.g., from galvanic and tailings effluents, mining waste heaps, as well as from electronic and electrical waste). 
The recycling of electrical and electronic scrap is most justifiable not only for environmental reasons but also for economic reasons due to the possibility of recovering valuable components $[4,5]$.

Precious metals in particular are valuable components. The electronics industry uses about $300 \mathrm{t}$ of gold per year (integrated circuits, contacts), which represents about $9 \%$ of the annual production of this metal. With gold contents of 300-350 g Au/t in mobile phones and $200-250 \mathrm{~g} \mathrm{Au} / \mathrm{t}$ in computer components, electronic scrap is a much richer carrier of precious metals compared to primary sources (about $5 \mathrm{~g} \mathrm{Au} / \mathrm{t}$ ore) [6].

In terms of materials, waste electronic equipment is a mixture of various metallic components (including $\mathrm{Zn}, \mathrm{Al}, \mathrm{Ni}, \mathrm{Fe}, \mathrm{Ga}$, Se, and $\mathrm{In}$ ), noble $\mathrm{Au}, \mathrm{Ag}, \mathrm{Pd}, \mathrm{Cu}$, and $\mathrm{Pt}$, hazardous substances $(\mathrm{Hg}, \mathrm{Be}, \mathrm{Pb}, \mathrm{As}, \mathrm{Cd}$, and $\mathrm{Sb})$, glass ceramics, and plastics [6,7].

The high content of $\mathrm{Al}, \mathrm{Fe}, \mathrm{Ni}, \mathrm{Cu}$, and $\mathrm{Pb}$, as well as $\mathrm{Au}, \mathrm{Ag}$, $\mathrm{Pd}$, and $\mathrm{Pt}$ in e-waste makes it a source for metal recovery. According to References $[1,8]$, the metal content of e-waste varies considerably depending on its type (Tables 1-3).

Table 1. Metal content in selected electronic devices, based on available online references [8].

\begin{tabular}{ccccccc}
\hline \multirow{2}{*}{ Type } & \multicolumn{3}{c}{ Content, $\%$} & \multicolumn{3}{c}{ Content, $\% \times \mathbf{1 0}^{-\mathbf{3}}$} \\
\cline { 2 - 7 } & $\mathbf{F e}$ & $\mathbf{A l}$ & $\mathbf{C u}$ & $\mathbf{A g}$ & $\mathbf{A u}$ & $\mathbf{P d}$ \\
\hline CD & 7 & 5 & 18 & 280 & 20 & 10 \\
Mobile & 7 & 3 & 13 & 900 & 200 & 80 \\
phone & & 2 & 5 & 115 & 15 & 4 \\
DVD & 62 & 5 & 3 & 260 & 50 & 5 \\
player & 4 & & &
\end{tabular}

Table 2. The typical composition of basic metals in PCBs, based on available online references [1].

\begin{tabular}{cccccccc}
\hline Name & Fe & Al & $\mathbf{C u}$ & $\mathbf{P b}$ & $\mathbf{Z n}$ & Sn & Ni \\
\hline Concentration $w t, \%$ & 20.47 & 14.17 & 6.93 & 6.30 & 2.20 & 1.01 & 0.85 \\
\hline
\end{tabular}

Table 3. Typical composition of valuable elements in PCB, based on available online references [1].

\begin{tabular}{ccccccccccccccc}
\hline Name & Ag & Ti & Ta & Co & Sb & Cd & As & Au & Se & Ge & Ga & Pd & Pt & Ni \\
\hline $\begin{array}{c}w t, \\
\% \times 10^{-3}\end{array}$ & 18.9 & 15.7 & 15.7 & 15.7 & 9.4 & 9.4 & 6.3 & 1.6 & 1.6 & 1.6 & 1.3 & 0.3 & 0.2 & 0.2 \\
\hline
\end{tabular}

The typical metal content in a printed circuit board (PCB) is shown in Tables 2 and 3 [1].

Although iron is dominant in terms of mass share (Tables 1 and 2), the value of e-waste is determined by the precious metal content [9]. A seemingly low concentration of these metals in electronic equipment units (less than $0.5 \%$ ), in terms of global sales, represents a significant share of PGM (precious group metals) production. Referring only to mobile phones and computer equipment, the shares are $4 \%$ of world Au production, $10 \%$ of $\mathrm{Ag}$, $7 \%$ of $\mathrm{Pt}$, and $48 \%$ of $\mathrm{Pd}$, respectively.

In 2019, formal documented collection and recycling amounted to $9.3 \mathrm{Mt}$, or $17.4 \%$ of the e-waste generated. This has increased by $1.8 \mathrm{Mt}$ since 2014, an annual increase of almost 0.4 Mt. However, the total amount of e-waste generated increased by $9.2 \mathrm{Mt}$, with an annual increase of almost $2 \mathrm{Mt}$. Therefore, recycling efforts have not kept pace with the global increase in e-waste. It is estimated that in 2030 the amount of e-waste generated will exceed $74 \mathrm{Mt}$ [10]. The statistical data on the collection and recycling rate in the world are presented in Figure 1. 


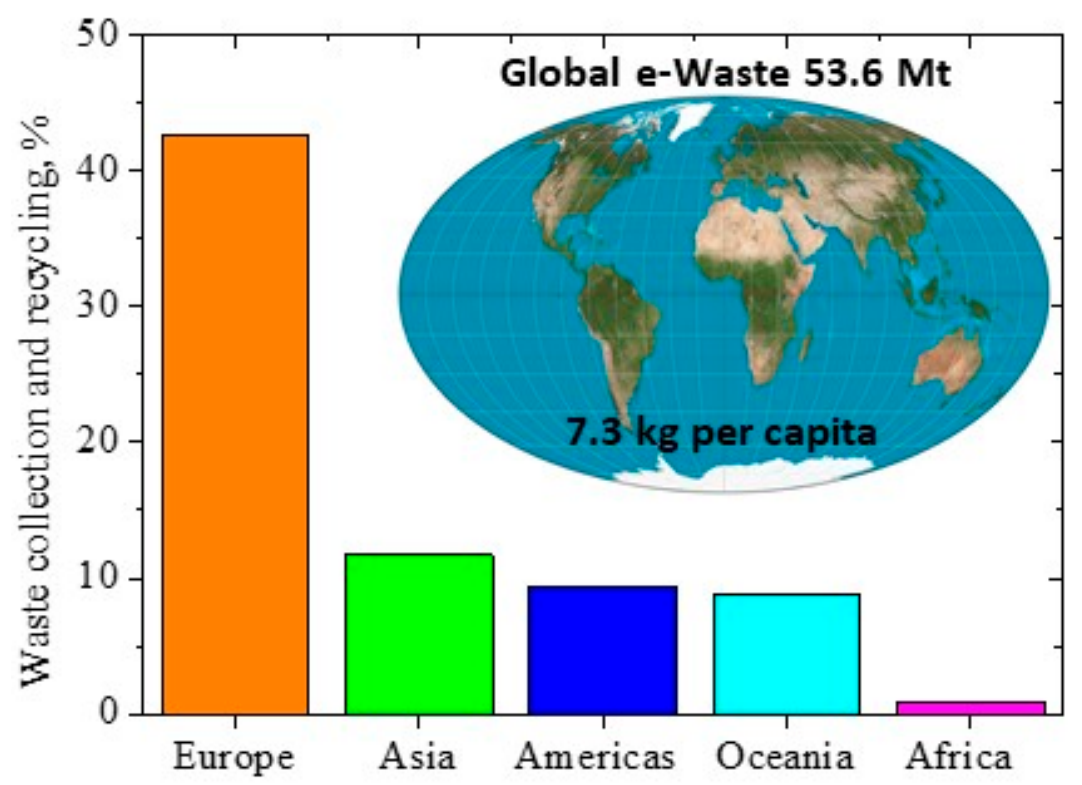

Figure 1. Global e-waste collection and recycling rates. Figure was made by authors.

Less than $40 \%$ of all e-waste in the EU is recycled. Recycling practices vary across the EU. In 2017 , Croatia recycled $81 \%$ of all electronic and electrical waste, compared to $21 \%$ in Malta $[8,11]$.

Pyrometallurgy and hydrometallurgy are two routes that are typically used to recover valuable metals. The traditional methods used to recover metals from electronic waste are pyrometallurgical methods (remelting in furnaces, sintering, melting, high-temperature gas phase reactions) $[12,13]$. However, in recent decades, the recovery of metals from e-waste via hydrometallurgical methods has been the area of the most intense research $[14,15]$. These methods are more accurate and do not require complex and expensive equipment [16]. The main steps of hydrometallurgical methods are the rinsing operations of solid electronic waste with acids or lyes [17]. The resulting solutions are then subjected to separation and purification (extraction, adsorption, or ion exchange) $[18,19]$.

Solvent extraction (SX) is one of the hydrometallurgical methods of great importance in the production of metals. The process has been in use for many years but still has great potential for future applications [20]. Many different extractants have been studied for PGM extraction, including quaternary ammonium salts [21-25], tertiary amide extractant [26], piperidine-based extractants [27], pyridine derivatives [28,29], hydroxyoximes [30], trialkylphosphine oxides [31], crown ethers [32], and $\beta$-diketone derivatives [33-35]. The separation of metal ions via solvent extraction depends mainly on the type of complexing reagent (extractant) and the effective solvent. Therefore, new complexing reagents are being sought to achieve the efficient separation of these ions from aqueous solutions.

The authors of this study decided to present the results of research on the usefulness of an amine derivative of $\beta$-diketone (ethylenodiamino-bis-acetylacetone (EDAB-acac)) in the separation of gold(III), platinum(IV), and palladium(II) ions from model solutions by $\mathrm{SX}$ in acidic medium.

Previously, EDAB-acac was used for Zn separation from a ternary Zn-Cr-Ni mixture [36] and a five-component $\mathrm{Zn}-\mathrm{Co}-\mathrm{Ni}-\mathrm{Cu}-\mathrm{Cd}$ mixture [37]. The zinc separation processes from these mixtures were carried out in a slightly alkaline (ammonia) environment with the use of polymer inclusion membranes.

When projecting the research described in this paper, the authors assumed that the use of differences in the complexing properties of $\mathrm{Pd}(\mathrm{II}), \mathrm{Pt}(\mathrm{IV})$, and $\mathrm{Au}(\mathrm{III})$ ions (i.e., differences in the formation of stable chelates with EDAB-acac in the $\mathrm{HCl}$ medium) will enable the separation of at least one or two examined metals. 


\section{Materials and Methods}

\subsection{Reagents}

Commercial $\mathrm{AuCl}_{3}$ (Sigma-Aldrich, Poznan, Poland), palladium chloride $\mathrm{PdCl}_{2}(99 \%$, Pol-Aura, Zabrze, Poland), $\mathrm{PtCl}_{4}$ (Pol-Aura, Zabrze, Poland), $\mathrm{HNO}_{3}$ (65\%, Avantor Performance Materials Poland S.A., Gliwice, Poland), $\mathrm{HCl}$ (35\%, Chempur, Piekary Slaskie, Poland), $\mathrm{NH}_{3 \mathrm{aq}}\left(25 \%\right.$, Chempur, Piekary Slaskie, Poland), $\mathrm{NH}_{4} \mathrm{SCN}$, and thiourea (both from Chempur, Piekary Slaskie, Poland) were used to prepare the initial solutions. Methylene chloride (Fluka, Busch, Switzerland), 2-ethylhexanol (99.6\%, Sigma-Aldrich, Poznan, Poland), chloroform, and toluene (both from Chempur, Piekary Slaskie, Poland) were used as extractant's diluents.

Ethylenodiamino-bis-acetylacetone (m.p. $110-111^{\circ} \mathrm{C}$ ) (Figure 2) was synthesized as a result of the condensation reaction of equimolar amounts of ethylenediamine with acetylacetone according to the procedure described in paper [38]. The structure has been confirmed in the nuclear magnetic resonance studies. The results are given in reference [38].<smiles>CC(=O)CC(C)=NCCN=C(C)CC(C)=O</smiles>

Figure 2. Structure of ethylenodiamino-bis-acetylacetone (EDAB-acac).

\subsection{Extraction and Stripping}

SX was carried out in the classical way at $20^{\circ} \mathrm{C}$. Both phases are shaken (volume ratio of aqueous (A) and organic phases $(\mathrm{O}) \mathrm{A} / \mathrm{O}=1$ ) for a period of time (from 1 to $20 \mathrm{~min}$ ), after which the phases were separated. The organic phase was stripped with water, $3 \mathrm{M}$ $\mathrm{HCl}, 3 \mathrm{M} \mathrm{HNO}_{3}, 0.5 \mathrm{M} \mathrm{NH}_{3(\mathrm{aq})}, 0.1 \mathrm{M}$ thiourea in $0.1 \mathrm{M} \mathrm{HCl}$ and also $0.5 \mathrm{M} \mathrm{HCl}(\mathrm{A} / \mathrm{O}=1)$.

The atomic absorption spectroscopy (AAS 240FS Spectrometer, Agilent, Santa Clara, CA, USA) or microwave plasma-atomic emission spectroscopy (4210 MP AES, Agilent, Santa Clara, CA, USA) was used to determine the concentrations of metal ions. The determination error did not exceed $5 \%$.

When $\mathrm{A} / \mathrm{O}=1$, the percentage extraction $(\mathrm{E}, \%)$ of each metal ion was calculated on the basis of changes in the concentration of metals in the aqueous phase before $\left([\mathrm{M}]_{\mathrm{i}}\right)$ and after $\left([\mathrm{M}]_{\mathrm{aq}}\right)$ extraction. Distribution ratio $(\mathrm{D})$ is defined as the ratio $\left([\mathrm{M}]_{\mathrm{i}}-[\mathrm{M}]_{\mathrm{aq}}\right) /[\mathrm{M}]_{\mathrm{aq}}$. Separation coefficient $\left(\mathrm{S}_{\mathrm{M} 1 / \mathrm{M} 2}\right)$ is defined as the ratio of the distribution ratios of these metals $\left(\mathrm{D}_{\mathrm{M} 1} / \mathrm{D}_{\mathrm{M} 2}\right)$.

\section{Results and Discussion}

\subsection{Extraction from One-Component System}

\subsubsection{Effect of Extraction Time}

The effect of time on the extraction of metal ions was investigated by the contacting of an aqueous phase containing $1 \mathrm{mM}$ single-component $\mathrm{Pd}(\mathrm{II}), \mathrm{Au}(\mathrm{III})$ or $\mathrm{Pt}(\mathrm{IV})$ ions in $0.1 \mathrm{M} \mathrm{HCl}$ with an organic phase containing $1 \mathrm{mM}$ EDAB-acac in methylene chloride.

The results are shown in Figure 3.

The extraction process (Figure 3), i.e., the partitioning of the studied metals from EDAB-acac occurs very rapidly. The equilibrium state is reached after only $5 \mathrm{~min}$. In further extraction studies, the phases were separated after $10 \mathrm{~min}$ of the process. 


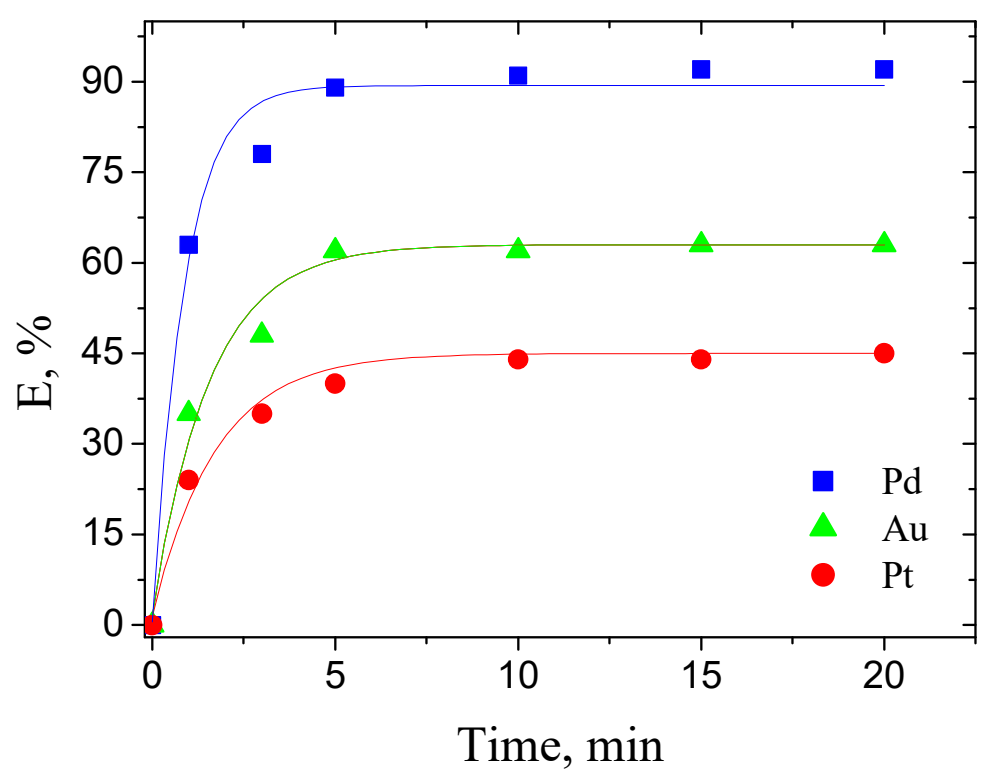

Figure 3. Effect of contact time on extraction of $\mathrm{Pd}(\mathrm{II}), \mathrm{Au}(\mathrm{III})$ and $\mathrm{Pt}(\mathrm{IV})$ ions with EDAB-acac in methylene chloride. The initial concentration of each metal ion is $1 \mathrm{mM}$.

\subsubsection{Effect of $\mathrm{HCl}$ Concentration}

The effect of $\mathrm{HCl}$ concentration on the extraction of $\mathrm{Pd}(\mathrm{II}), \mathrm{Au}(\mathrm{III})$ and $\mathrm{Pt}(\mathrm{IV})$ with EDAB-acac extractant was investigated and shown in Figure 4. The concentration of $\mathrm{HCl}$ in the aqueous phase was altered between 0.1 and $5 \mathrm{M}$.

The extraction efficiency $(\% \mathrm{E})$ of each of the studied metal ions strongly depends on the $\mathrm{HCl}$ concentration in the aqueous phase (Figure 4). The highest values of extraction percentage were obtained for $0.1 \mathrm{M} \mathrm{HCl}$. These are $95 \%, 65 \%$, and $47 \%$ for $\mathrm{Pd}(\mathrm{II}), \mathrm{Au}(\mathrm{III})$, and $\mathrm{Pt}(\mathrm{IV})$, respectively.

$\mathrm{Pd}(\mathrm{II}), \mathrm{Au}(\mathrm{III})$, and $\mathrm{Pt}(\mathrm{IV})$ ions in an aqueous phase at the presence of chloride ions form a series of anionic chloro complexes with the general formula $\left[\mathrm{MCl}_{n}\right]^{\mathrm{z}-}$, in which $\mathrm{n}$ varies from 1 to $\mathrm{N}$ ( $\mathrm{N}$-maximum coordination number). In the studied $\mathrm{HCl}$ concentration range (0.1-5 M), $\mathrm{Pd}(\mathrm{II})$ and $\mathrm{Au}(\mathrm{III})$ ions form 4-coordinated, square planar complexes with the formulas $\left[\mathrm{PdCl}_{4}\right]^{2-}$ and $\left[\mathrm{AuCl}_{4}\right]^{-}$, respectively, while $\mathrm{Pt}(\mathrm{IV})$ ions form 6-coordinated octahedral complexes $\left(\left[\mathrm{PtCl}_{6}\right]^{2-}\right.$ ) (Figure 5) $[39,40]$.

Increasing the $\mathrm{HCl}$ concentration in the aqueous phase decreases the extraction percentage of each cation. Perhaps the cause is the competitive ion pair formation reaction [HEDAB-acac ${ }^{+} \mathrm{Cl}^{-}$or $\left[\mathrm{H}_{2}\right.$ EDAB-acac ${ }^{2+} 2 \mathrm{Cl}^{-}$.

For $5 \mathrm{M} \mathrm{HCl}$, the extraction percentages are only $36 \%, 20 \%$, and $18 \%$ for $\mathrm{Pd}(\mathrm{II}), \mathrm{Au}(\mathrm{III})$, and $\mathrm{Pt}(\mathrm{IV})$, respectively.

\subsubsection{Equilibrium of $\mathrm{Pd}(\mathrm{II}), \mathrm{Au}(\mathrm{III})$, and $\mathrm{Pt}(\mathrm{IV})$ Extraction}

The extraction isotherms of $\mathrm{Pd}(\mathrm{II}), \mathrm{Au}(\mathrm{III})$, and $\mathrm{Pt}(\mathrm{IV})$ from a $0.1 \mathrm{M} \mathrm{HCl}$ solution using EDAB-acac in methylene chloride are shown in Figure 6. The concentration of metal ions was altered between 0.5 and $5 \mathrm{mM}$, while the amount of EDAB-acac was fixed ( $2 \mathrm{mM}$ ). 


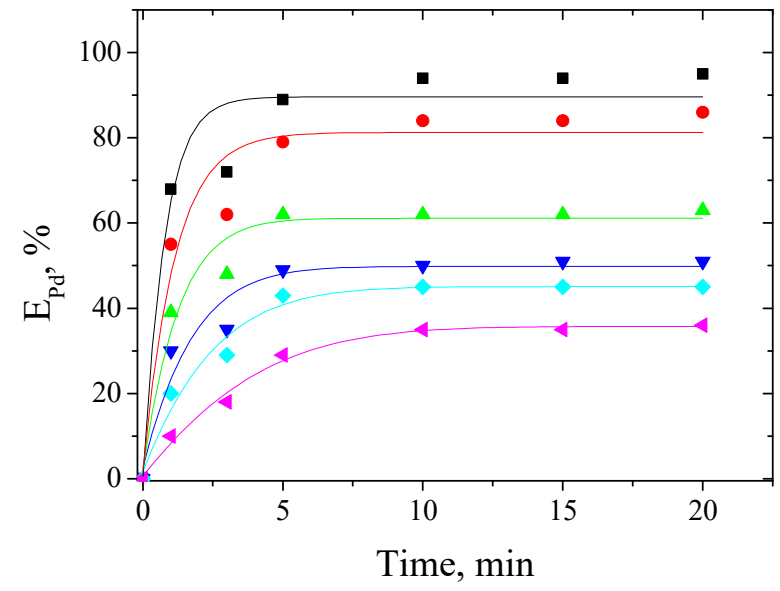

(A)

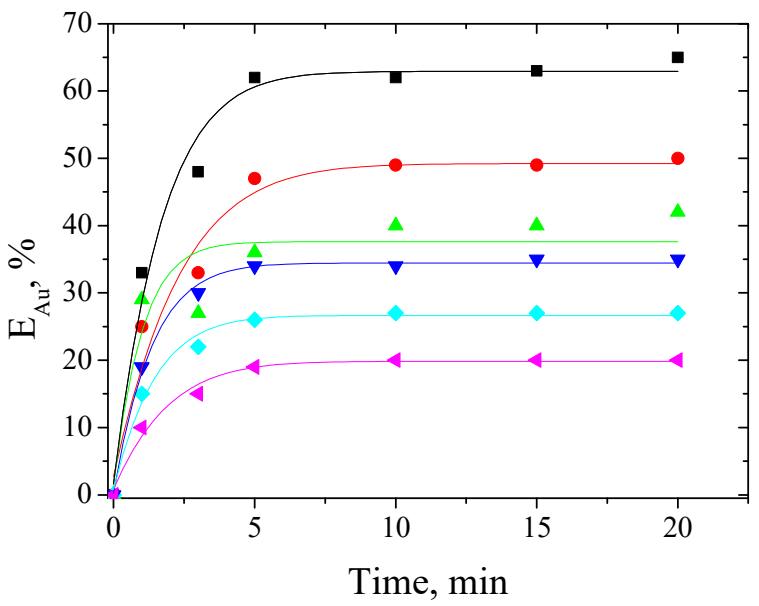

(B)

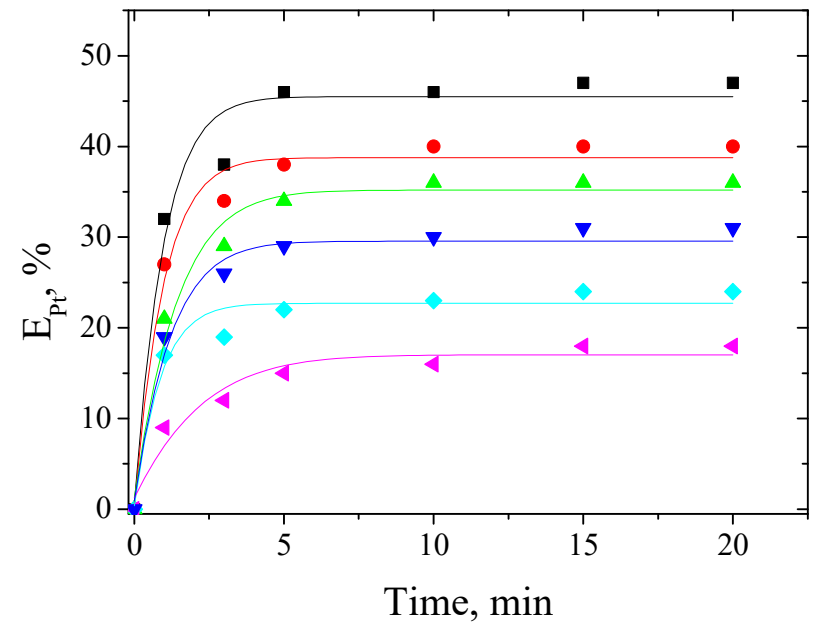

(C)

Figure 4. Effect of $\mathrm{HCl}$ concentration on extraction of $\mathrm{Pd}(\mathrm{II})(\mathbf{A}), \mathrm{Au}(\mathrm{III})(\mathbf{B})$, and $\mathrm{Pt}(\mathrm{IV})(\mathbf{C})$ with EDAB-acac in methylene chloride for $-0.1 ; \bullet-0.5 ; \boldsymbol{\Delta}-1 ; \mathbf{\nabla}-2 ;-3$; and $\triangleleft-5 \mathrm{M} \mathrm{HCl}$ concentration. The initial concentration of each metal ion is $1 \mathrm{mM}$.

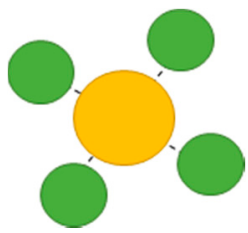

tetrachloroaurate $\left[\mathrm{AuCl}_{4}\right]^{-}$

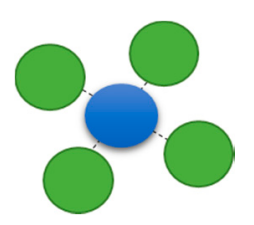

tetrachloropalladate $\left[\mathrm{PdCl}_{4}\right]^{2-}$

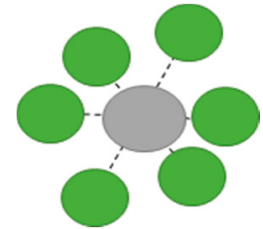

hexachloroplatinate $\left[\mathrm{PtCl}_{6}\right]^{2-}$

Figure 5. Structure of $\mathrm{Pd}(\mathrm{II}), \mathrm{Au}(\mathrm{III})$, and $\mathrm{Pt}(\mathrm{IV})$ chlorocomplexes. Figure was made by authors. 


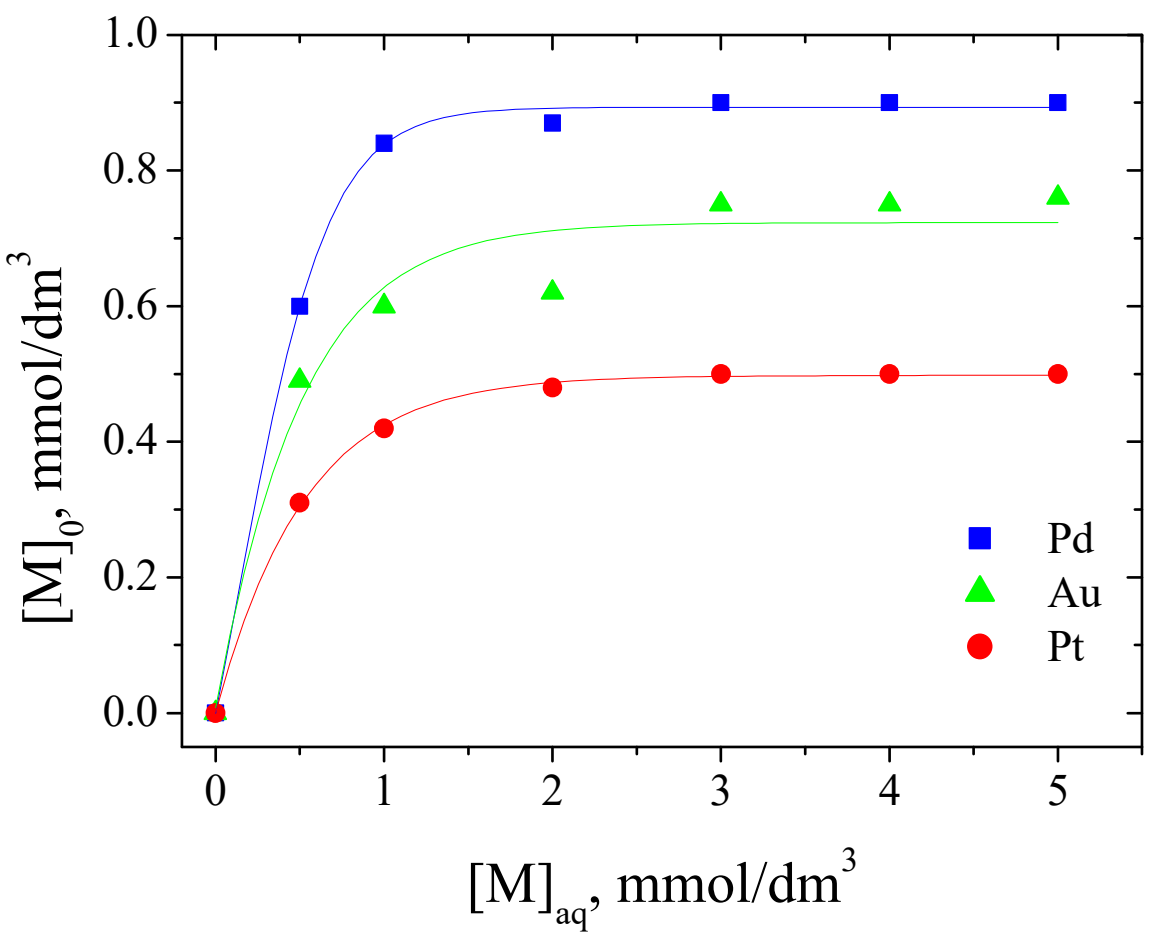

Figure 6. Extraction isotherms of $\mathrm{Pd}(\mathrm{II}), \mathrm{Au}(\mathrm{III})$, and $\mathrm{Pt}(\mathrm{IV})$ ions with EDAB-acac in methylene chloride. Initial concentration of each metal ions in the range of 0.5 and $5 \mathrm{mM}$.

As can be seen from Figure 6, the maximum EDAB-acac capacities for $\mathrm{Pd}(\mathrm{II}), \mathrm{Au}(\mathrm{III})$, and $\mathrm{Pt}(\mathrm{IV})$ are $0.9 \mathrm{mM}, 0.75 \mathrm{mM}$, and $0.5 \mathrm{mM}$, respectively.

The extraction process can probably be described by the following equations:

$$
\begin{gathered}
\mathrm{L}_{(\text {org })}+2 \mathrm{H}^{+}+2 \mathrm{Cl}^{-}=\left[\left(\mathrm{LH}_{2}\right)^{2+} 2 \mathrm{Cl}^{-}\right]_{(\mathrm{org})} \\
{\left[\mathrm{PdCl}_{4}\right]^{2-}+\left[\left(\mathrm{LH}_{2}\right)^{2+} 2 \mathrm{Cl}^{-}\right]=\left[\left(\mathrm{LH}_{2}\right) \mathrm{PdCl}_{4}\right]+2 \mathrm{Cl}^{-}} \\
{\left[\mathrm{PtCl}_{6}\right]^{2-}+\left[\left(\mathrm{LH}_{2}\right)^{2+} 2 \mathrm{Cl}^{-}\right]=\left[\left(\mathrm{LH}_{2}\right) \mathrm{PtCl}_{6}\right]+2 \mathrm{Cl}^{-}} \\
{\left[\mathrm{AuCl}_{4}\right]^{-}+\left[\left(\mathrm{LH}_{2}\right)^{2+} 2 \mathrm{Cl}^{-}\right]=\left[\left(\mathrm{LH}_{2}\right)\left(\mathrm{AuCl}_{4}\right)_{2}\right]+2 \mathrm{Cl}^{-}}
\end{gathered}
$$

According to the above equations, the extractant (L) (EDAB-acac) is first protonated in an acidic solution. Metal ions in $\mathrm{HCl}$ medium form an anionic chlorocomplex, which is extracted into the organic phase according to the ion exchange mechanism. This mechanism is consistent with that of $\mathrm{Pd}(\mathrm{II})$ extraction with amines [41-43].

\subsubsection{FT-IR Analysis of the Methylene Chloride Phase}

Spectrophotometric studies of the organic phase (methylene chloride) were carried out using a Bruker INVENIO R infrared spectrophotometer (Ettlingen, Germany) equipped with a broadband BeamSplitter and an ATR Quest attachment from Specac (Orpington, UK). The study was carried out in the wave range from $4000 \mathrm{~cm}^{-1}$ to $450 \mathrm{~cm}^{-1}$.

FT-IR spectra were performed for an organic phase (methylene chloride) containing EDAB-acac and $\mathrm{PdCl}^{4-}$ ions (molar ratio 1:1). The spectrum is shown in Figure 7 together with a spectrum for a solution containing only the ligand (extractant). 

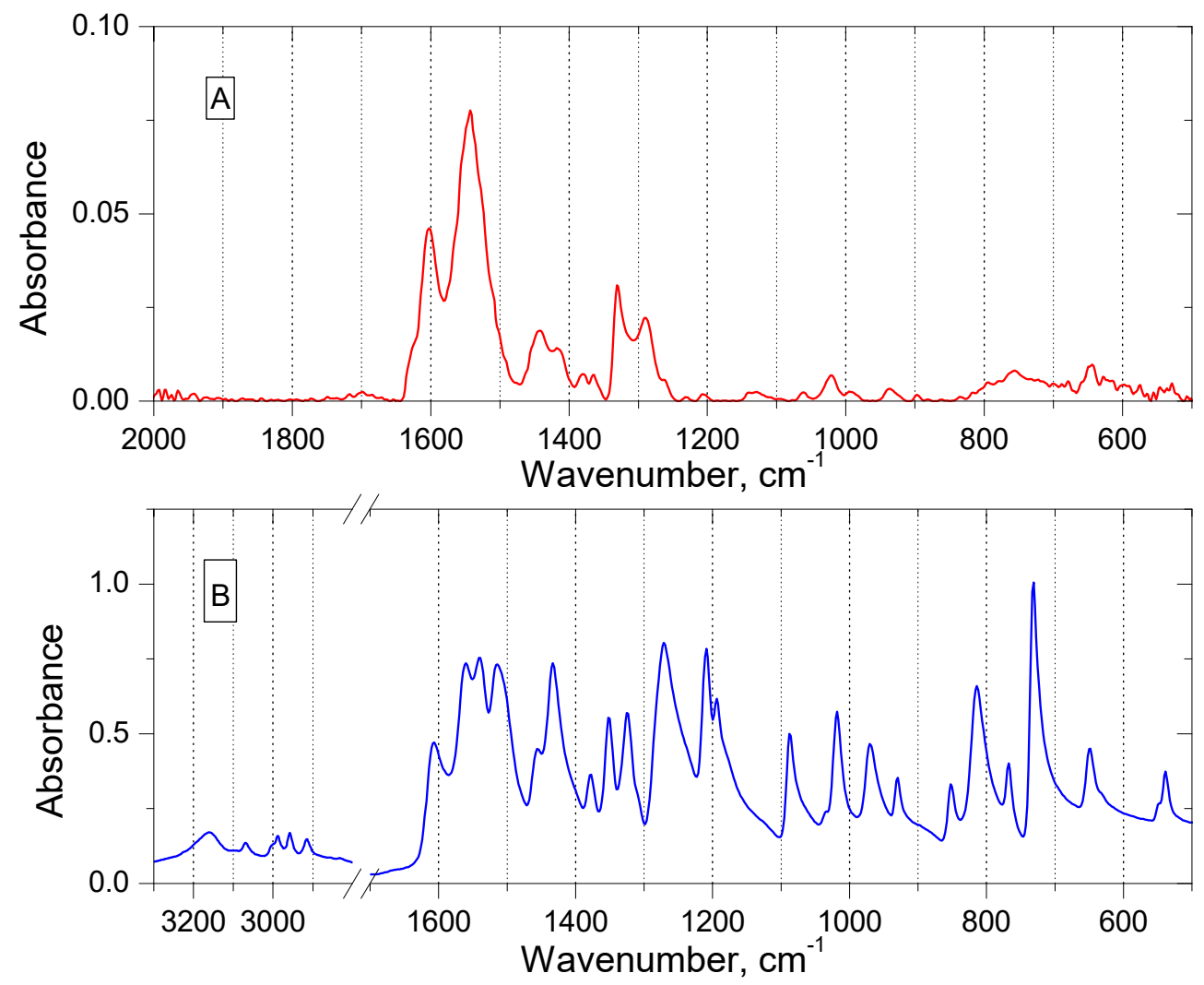

Figure 7. FT-IR spectra of the Pd(II)-chloro-EDAB-acac salt (A) and EDAB-acac (B) solution in methylene chloride.

IR experiments were interpreted using the IRPal 2.0 software. As can be seen in Figure 7, FT-IR measurements confirm that $\mathrm{Pd}(\mathrm{II})$ is transported into the organic phase by the interaction between the extractant (EDAB-acac) and the $\mathrm{PdCl}_{4}{ }^{2-}$ ions, probably as a $\left[\left(\mathrm{H}_{2} \mathrm{EDAB}-\mathrm{acac}\right) \mathrm{PdCl}_{4}\right]$. In the extractant spectrum, the signals corresponding to the $\mathrm{C}=\mathrm{O}$ and $\mathrm{C}=\mathrm{N}$ bonds are located at $1606 \mathrm{~cm}^{-1}$ and $1560 \mathrm{~cm}^{-1}$, respectively. The wide signal within the range of $3150-2990 \mathrm{~cm}^{-1}$ corresponds to the stretching vibration in the O-H group formed by the enol form of the extractant. Signals within the range of $1510-1430 \mathrm{~cm}^{-1}$ and $1430-1090 \mathrm{~cm}^{-1}$ corresponded to deformation $\mathrm{N}-\mathrm{H}$ and stretching vibrations C-O, respectively. The intense bands were observed in the range of $910-970 \mathrm{~cm}^{-1}$ (vibrations of the $\mathrm{CH}_{2}$ group) and at $770 \mathrm{~cm}^{-1}$ (vibrations $\mathrm{C}-\mathrm{C}$ ). The interaction with $\mathrm{Pd}$ (II) caused changes in spectral regions. Namely, changes in the intensity of the vibrational bands $\mathrm{C}=\mathrm{O}\left(\right.$ at $\left.1600 \mathrm{~cm}^{-1}\right), \mathrm{C}=\mathrm{N}$ (at $1540 \mathrm{~cm}^{-1}$ ) were observed. The bands stretching both the $\mathrm{O}-\mathrm{H}$ bonds of the enol form (around $3000 \mathrm{~cm}^{-1}$ ) and the $\mathrm{C}-\mathrm{O}$ bonds were disappearing.

\subsection{Extraction from Three-Component System}

Influence of the Diluent on the Extraction Efficiency

Different diluents of various nature were used to examine the solvent influence on $\mathrm{Au}(\mathrm{III}), \mathrm{Pd}(\mathrm{II})$ and $\mathrm{Pt}(\mathrm{IV})$ extraction efficiency. Table 4 shows the results for the extraction of metal ions from $0.1 \mathrm{M} \mathrm{HCl}$ with EDAB-acac in toluene, chloroform, methylene chloride, and 2-ethylhexanol. 
Table 4. Extraction of mixture $\mathrm{Au}(\mathrm{III}), \mathrm{Pd}(\mathrm{II})$, and $\mathrm{Pt}(\mathrm{IV})$ with EDAB-acac in different diluents from acidic medium $(0.1 \mathrm{M} \mathrm{HCl})$. The initial concentration of each metal ion was $1 \mathrm{mM}$.

\begin{tabular}{|c|c|c|c|c|c|}
\hline Metal Ion & Dilutent & $\mathrm{E}, \%$ & $D_{M}$ & \multicolumn{2}{|c|}{ Separation Coefficient } \\
\hline $\operatorname{Pd}(\mathrm{II})$ & & 54 & 1.2 & & \\
\hline $\mathrm{Au}(\mathrm{III})$ & toluene & 35 & 0.5 & 2.4 & 12.0 \\
\hline $\operatorname{Pt}(\mathrm{IV})$ & & 12 & 0.1 & & \\
\hline $\mathrm{Pd}(\mathrm{II})$ & & 87 & 6.7 & & \\
\hline $\mathrm{Au}(\mathrm{III})$ & chloroform & 56 & 1.3 & 5.2 & 13.4 \\
\hline $\operatorname{Pt}(\mathrm{IV})$ & & 31 & 0.5 & & \\
\hline $\operatorname{Pd}(\mathrm{II})$ & & 95 & 10.1 & & \\
\hline $\mathrm{Au}(\mathrm{III})$ & methylene chloride & 59 & 1.4 & 7.2 & 12.6 \\
\hline $\operatorname{Pt}(\mathrm{IV})$ & & 44 & 0.8 & & \\
\hline $\operatorname{Pd}(\mathrm{II})$ & & 93 & 13.3 & & \\
\hline $\mathrm{Au}(\mathrm{III})$ & 2-ethylhexanol & 62 & 1.6 & 8.3 & 19.0 \\
\hline $\mathrm{Pt}(\mathrm{IV})$ & & 40 & 0.7 & & \\
\hline
\end{tabular}

Table 4 shows that $\mathrm{Pd}(\mathrm{II})$ and $\mathrm{Au}(\mathrm{III})$ ions are most easily extracted from the threecomponent Pd-Au-Pt mixture by EDAB-acac, as they can form 4-coordinated planar complexes. The efficiency of the process depends not only on the type of metal ion but also on the diluent used. Depending on the type of diluent, the Pd extraction varies from $54 \%$ (toluene) to $95 \%$ (methylene chloride). The best diluent conducive to extraction is methylene chloride and 2-ethylhexanol. That might be related to the solvation potential of the extractable complexes. The possibility of solvation is related to the values of diluent donor numbers $[44,45]$. According to Guttman [46], the donor number (DN) of toluene, methylene chloride, chloroform and 2-ethylhexanol was $0.1,1,4$, and 48, respectively. As a result of solvation, the hydrophobicity of the extractable complexes increases; hence, diluents with high donor numbers increase the extraction of $\mathrm{Pd}$ and $\mathrm{Au}$ as well as increase the separation coefficients of $\mathrm{Pd}$ in relation to $\mathrm{Au}$ and $\mathrm{Pt}$ (Table 4).

\subsection{Stripping Experiments}

The stripping of $\mathrm{Au}(\mathrm{III}), \mathrm{Pd}(\mathrm{II})$, and $\mathrm{Pt}(\mathrm{IV})$ from the EDAB-acac-methylene chloride phase was investigated. Aqueous solutions like $0.5 \mathrm{M}$ aqueous ammonia, $0.5 \mathrm{M} \mathrm{NH}_{4} \mathrm{SCN}$, $5 \mathrm{M} \mathrm{HCl}, 5 \mathrm{M} \mathrm{HNO}_{3}, 0.1 \mathrm{M}$ thiourea in $0.1 \mathrm{M} \mathrm{HCl}$ and $1.0 \mathrm{M} \mathrm{HCl}$ and also distilled water were used as stripping reagents.

The data obtained for stripping solutions studied are summarized in Table 5.

Table 5. The metal ion stripping percentages obtained for the stripping solutions studied after EDAB-acac in methylene chloride extraction.

\begin{tabular}{cccc}
\hline \multirow{2}{*}{ Stripping Solution } & \multicolumn{3}{c}{ Stripping Percent, $\%$} \\
\cline { 2 - 4 } & $\mathbf{P d}$ & $\mathbf{A u}$ & $\mathbf{P t}$ \\
\hline Water & 0 & 0 & 0 \\
$0.5 \mathrm{M} \mathrm{ammonia} \mathrm{aq.}$ & 100 & 0 & 0 \\
$0.5 \mathrm{M} \mathrm{NH}_{4} \mathrm{SCN}$ & 96 & 10 & 63 \\
$5 \mathrm{M} \mathrm{HCl}^{\mathrm{M} \mathrm{HNO}}$ & 70 & 2 & 32 \\
$3 \mathrm{M} \mathrm{HCl}_{0.1 \mathrm{M} \text { thiourea in } 0.1 \mathrm{M} \mathrm{HCl}}$ & 15 & 0 & 99 \\
$0.1 \mathrm{M}$ thiourea in $1.0 \mathrm{M} \mathrm{HCl}$ & 100 & 100 & 20 \\
\hline
\end{tabular}

The stripping with distilled water is not possible. The most efficient stripping of $\operatorname{Pd}(\mathrm{II})$ ions was achieved using $0.5 \mathrm{M} \mathrm{NH}_{3 a q}, 0.1 \mathrm{M}$ thiourea in $0.1 \mathrm{M}$ and also in $1.0 \mathrm{M} \mathrm{HCl}$, and the percentage of $\mathrm{Pd}(\mathrm{II})$ stripping was $100 \%$. The use of $0.5 \mathrm{M} \mathrm{NH}_{4} \mathrm{SCN}$ allow for the 
recovery of $\mathrm{Pd}(\mathrm{II}) 96 \%$ in a single-step process. $5 \mathrm{M} \mathrm{HNO}_{3}$ quantitatively strips $\mathrm{Pt}(\mathrm{IV})$ ions while $0.1 \mathrm{M}$ thiourea in both $0.1 \mathrm{M}$ and $1.0 \mathrm{M} \mathrm{HCl}$ were complete stripping $\mathrm{Au}(\mathrm{III})$ ions.

The metal ions can be separated from the Pd-Au-Pt mixture via a 3-step stripping process. In the first stripping step, the organic phase is treated with $5 \mathrm{M} \mathrm{HNO}_{3}(\mathrm{Pt}$ separation), followed by the use of $0.5 \mathrm{M}$ aqueous ammonia (Pd separation) and, finally, $0.1 \mathrm{M}$ thiourea in $\mathrm{HCl}$ (completely stripped $\mathrm{Au}$ ). In the first proposed stripping step, nevertheless, $45 \% \mathrm{Pd}(\mathrm{II})$ would be stripped together with $\mathrm{Pt}(\mathrm{IV})$,

\subsection{Recovery of Pd(II), Au(III), and Pt(IV) from Model Waste Solution}

The next step of our work was to investigate the possibility of selective separation and recovery of palladium, gold, and platinum from the model solution with the composition corresponding to the composition of the solution after leaching of the spent e-waste. According to $\mathrm{Lu}$ and $\mathrm{Xu}$ [9], a typical solution after leaching e-waste with hydrochloric acid contains $10 \mathrm{mg} / \mathrm{dm}^{3} \mathrm{Pd}, 8 \mathrm{mg} / \mathrm{dm}^{3} \mathrm{Pt}$, and $10 \mathrm{mg} / \mathrm{dm}^{3} \mathrm{Au}$. For the next experiment, a 3-component solution was prepared with the composition given in the literature [9] and $0.1 \mathrm{M} \mathrm{HCl}$ was added. Metal ions were extracted with a solution of EDAB-acac in methylene chloride. After $10 \mathrm{~min}$, phases were separated and the concentrations of the $\mathrm{Pd}(\mathrm{II}), \mathrm{Au}(\mathrm{III})$, and $\mathrm{Pt}(\mathrm{IV})$ ions remaining in the aqueous phase were determined. The stripping of $\mathrm{Au}(\mathrm{III}), \mathrm{Pd}(\mathrm{II})$, and $\mathrm{Pt}(\mathrm{IV})$ from the organic phase was studied with $0.1 \mathrm{M}$ thiourea in $0.1 \mathrm{M} \mathrm{HCl}$. Table 6 shows the extraction efficiency $(\mathrm{E}, \%)$ and the stripping percentage of $\mathrm{Au}(\mathrm{III}), \mathrm{Pd}(\mathrm{II})$, and $\mathrm{Pt}(\mathrm{IV})$ from the e-waste model solution.

Table 6. The extraction efficiency (E,\%) and the stripping percent of $\mathrm{Au}(\mathrm{III}), \mathrm{Pd}(\mathrm{II})$, and $\mathrm{Pt}(\mathrm{IV})$ from the e-waste model solution. Initial concentration of metals: $10 \mathrm{mg} / \mathrm{dm}^{3} \mathrm{Pd}, 8 \mathrm{mg} / \mathrm{dm}^{3} \mathrm{Pt}$, and $10 \mathrm{mg} / \mathrm{dm}^{3} \mathrm{Au}$.

\begin{tabular}{cccc}
\hline Metals & Pd(II) & Pt(IV) & Au(III) \\
\hline Extraction E, \% & 82 & 2 & 60 \\
Stripping percent, \% & 90 & - & 94 \\
\hline
\end{tabular}

The data in Table 6 shows that only Pd(II) and Au(III) ions are extracted. Pt(IV) ions remain in the water phase. The stripping solution allows for the recovery of $90 \%$ of $\operatorname{Pd}(\mathrm{II})$ and $94 \%$ of $\mathrm{Au}(\mathrm{III})$. The EDAB-acac can be used as the extractant for the separation of $\mathrm{Pd}(\mathrm{II})$ and $\mathrm{Au}(\mathrm{III})$ ions from leach solutions of e-waste.

\section{Conclusions}

The conducted research shows that a new amine derivative of $\beta$-diketone (EDAB-acac) can be successfully used in an acidic medium to separate a mixture containing $\mathrm{Pd}(\mathrm{II}), \mathrm{Au}(\mathrm{III})$ and $\mathrm{Pt}(\mathrm{IV})$ ions by an extraction method. Increasing the $\mathrm{HCl}$ concentration decreases the extraction percentage of each ion. Perhaps the cause is the competitive ion pair formation reaction $[\mathrm{HEDAB}-\mathrm{acac}]^{+} \mathrm{Cl}^{-}$or $\left[\mathrm{H}_{2} \mathrm{EDAB}-\mathrm{acac}\right]^{2+} 2 \mathrm{Cl}^{-}$. The highest values of extraction percentage were obtained for $0.1 \mathrm{M} \mathrm{HCl}$. For single solutions of $\mathrm{Pd}(\mathrm{II}), \mathrm{Au}(\mathrm{III})$, and $\mathrm{Pt}(\mathrm{IV})$ ions, they are $95 \%, 65 \%$, and $47 \%$, respectively. The extraction efficiency with EDAB-acac is lower from a 3-component mixture of Pd-Au-Pt in $0.1 \mathrm{M} \mathrm{HCl}$ medium. Pd(II) (87-96\%) and $\mathrm{Au}(\mathrm{III})(56-62 \%)$ ions that form 4-coordinated planar complexes $\left(\left[\mathrm{PdCl}_{4}\right]^{2-}\right.$ and $\left.\left[\mathrm{AuCl}_{4}\right]^{-}\right)$ are the easiest to extract. The efficiency of the process depends not only on the metal ion but also on the used diluent. Diluents with high donor numbers increase the hydrophobicity of the extracted complexes due to solvation, thus increasing both the extraction percentage of $\mathrm{Pd}$ and $\mathrm{Au}$ as well as the separation coefficients of $\mathrm{Pd}$ relative to $\mathrm{Au}$ and $\mathrm{Pt}$.

Palladium(II), gold(III), and platinum(IV) can be successfully separated from the $\mathrm{Pd}-\mathrm{Au}-\mathrm{Pt}$ mixture in a 3-step stripping process. In the first stripping step, the aqueous phase should be treated with $5 \mathrm{M} \mathrm{HNO}_{3}$ (Pt and 45\% Pd separation), followed by the application of $0.5 \mathrm{M}$ aqueous ammonia (Pd separation), and, finally, $0.1 \mathrm{M}$ thiourea in $\mathrm{HCl}$ (Au separation). 
In an acidic medium, the EDAB-acac can be used as an extractant for the separation of $\mathrm{Pd}(\mathrm{II})$ and $\mathrm{Au}(\mathrm{III})$ ions from e-waste leach solutions.

Author Contributions: Conceptualization, E.R.-L.; methodology, E.R.-L. and A.K.; software, I.P. and A.K.; validation, E.R.-L., I.P. and A.K.; formal analysis, E.R.-L., I.P. and A.K.; investigation, E.R.-L., I.P. and A.K.; writing—original draft preparation, A.K.; writing—review and editing, E.R.-L. and I.P.; visualization, E.R.-L., I.P. and A.K. All authors have read and agreed to the published version of the manuscript.

Funding: The financial support of the Ministry of Science and Higher Education RP (BN 10/2019) is gratefully acknowledged.

Institutional Review Board Statement: Not applicable.

Informed Consent Statement: Not applicable.

Data Availability Statement: Not applicable.

Conflicts of Interest: The authors declare no conflict of interest.

\section{References}

1. Debnath, B.; Chowdhury, R.; Ghosh, S.K. Sustainability of metal recovery from E-waste. Front. Environ. Sci. Eng. 2018, $12,2$. Available online: http:/ /hdl.handle.net/20.500.11794/24666 (accessed on 14 April 2021). [CrossRef]

2. Perkins, D.N.; Brune Drisse, M.N.; Nxele, T.; Sly, P.D. E-waste: A global hazard. Ann. Glob. Health 2014, 80, $286-295$. [CrossRef] [PubMed]

3. BASF Catalysts-Metal Prices. Available online: https://apps.catalysts.basf.com/apps/eibprices/mp/ (accessed on 19 April 2021).

4. Reck, B.K.; Graedel, T.E. Challenges in metal recycling. Science 2012, 337, 690-695. [CrossRef] [PubMed]

5. O'Connor, M.P.; Zinnerman, J.B.; Anastas, P.T.; Plata, D.L. A strategy for material supply chain sustainability: Enabling a circular economy in the electronics industry through green engineering. ACS Sustain. Chem. Eng. 2016, 4, 5879-5888. [CrossRef]

6. Hagelüken, C.; Corti, C.W. Recycling of gold from electronics: Cost-effective use through 'Design for Recycling'. Gold Bull. 2010, 43, 209-220. [CrossRef]

7. Hall, W.J.; Williams, P.T. Separation and recovery of materials from scrap printed circuit boards. Resour. Conserv. Recycl. 2007, 51, 691-709. [CrossRef]

8. Forti, V.; Baldé, C.P.; Kuehr, R.; Bel, G. The Global E-waste Monitor 2020: Quantities, Flows and the Circular Economy Potential. United Nations University (UNU)/United Nations Institute For Training And Research (UNITAR)—Co-hosted SCYCLE Programme, International Telecommunication Union (ITU) \& International Solid Waste Association (ISWA), Bonn/Geneva/Rotterdam. Available online: https:/ / collections.unu.edu/view/UNU:7737 (accessed on 30 June 2021).

9. $\mathrm{Lu}, \mathrm{Y}$; $\mathrm{Xu}, \mathrm{Z}$. Precious metals recovery from waste printed circuit boards: A review for current status and perspective. Resour. Conserv. Recycl. 2016, 113, 28-39. [CrossRef]

10. Willer, J.; Fornalczyk, A. Electronic scraps as a source of precious metals. Przemysl Chem. 2012, 91, 517-522.

11. E-waste Guide Info. E-waste in the EU: Facts and Figures. Available online: https://www.europarl.europa.eu/news/en/ headlines/ society / 20201208STO93325/e-waste-in-the-eu-facts-and-figures-infographic (accessed on 10 June 2021).

12. Sanito, R.C.; You, S.-J.; Wang, j.-F. Application of plasma technology for treating e-waste: A review. J. Environ. Manag. 2021, 188, 112380. [CrossRef] [PubMed]

13. Cui, J.; Zhang, L. Metallurgical recovery of metals from electronic waste: A review. J. Hazard. Mater. 2008, 158, 228-256. [CrossRef]

14. Islam, A.; Ahmed, T.; Awual, M.R.; Rahman, A.; Sultana, M.; Aziz, A.A.; Monir, M.U.; Teo, S.H.; Hasan, M. Advances in sustainable approaches to recover metals from e-waste-A review. J. Clean. Product. 2020, 244, 118815. [CrossRef]

15. Tuncuk, A.; Stazi, V.; Akcil, A.; Yazici, E.Y.; Deveci, H. Aqueous metal recovery techniques from e-scrap: Hydrometallurgy in recycling. Miner. Eng. 2012, 25, 28-37. [CrossRef]

16. Andrews, D.; Raychaudhuri, A.; Frias, C. Environmentally sound technologies for recycling secondary lead. J. Power Sources 2000, 88, 124-129. [CrossRef]

17. Sun, Z.; Cao, H.; Xiao, Y.; Sietsma, J.; Jin, W.; Agterhuis, H.; Yang, Y. Toward sustainability for recovery of critical metals from electronic waste: The hydrochemistry processes. ACS Sustain. Chem. Eng. 2017, 5, 21-40. [CrossRef]

18. Akcil, A.; Erust, C.; Gahan, C.S.; Ozgun, M.; Sahin, M.; Tuncuk, A. Precious metal recovery from waste printed circuit boards using cyanide and non-cyanide lixiviants-A review. Waste Manag. 2015, 45, 258-271. [CrossRef]

19. Jadhav, U.; Hocheng, H. Hydrometallurgical recovery of metals from large printed circuit board pieces. Sci. Rep. 2015, 5, 14574. [CrossRef] [PubMed]

20. Free, M.L. Hydrometallurgy: Fundamentals and Applications; Wiley \& Sons Inc.: Hoboken, NJ, USA, 2013.

21. Kejun, L.; Yen, W.T.; Shibayama, A.; Miyazaki, T.; Fujita, T. Gold extraction from thiosulfate solution using trioctylmethylammonium chloride. Hydrometallurgy 2004, 73, 41-53. [CrossRef] 
22. Fontana, D.; Pietrantonio, M.; Pucciarmati, S.; Torelli, N.G.; Bonomi, C. Palladium recovery from monolithic ceramic capacitors by leaching, solvent extraction and reduction. J. Mater. Cycles Waste Manag. 2017, 20. [CrossRef]

23. Oshima, T.; Iwao, S.; Matsuo, N.; Ohe, K. Extraction behavior of precious metals in hydrochloric-acid media using a novel amine extractant bearing a furan group. Solv. Extr. Res. Dev. Jpn. 2019, 26, 69-80. [CrossRef]

24. Nguyen, T.H.; Sonu, C.H.; Lee, M.S. Separation of platinum(IV) and palladium(II) from concentrated hydrochloric acid solutions by mixtures of amines with neutral extractants. J. Ind. Eng. Chem. 2015, 32, 238-245. [CrossRef]

25. Wei, W.; Cho, C.W.; Kim, S.; Song, M.H.; Kwame Bediako, J.; Yun, Y.S. Selective recovery of Au(III), Pt(IV), and Pd(II) from aqueous solutions by liquid-liquid extraction using ionic liquid Aliquat-336. J. Mol. Liq. 2016, 216, 18-24. [CrossRef]

26. Rao, M.D.; Singh, K.K.; Morrison, C.A.; Love, J.B. Recycling copper and gold from e-waste by a two-stage leaching and solvent extraction process. Sep. Purif. Technol. 2021, 263, 118400. [CrossRef]

27. Cieszynska, A.; Wieczorek, D. Extraction and separation of palladium (II), platinum (IV), gold (III) and rhodium (III) using piperidine-based extractants. Hydrometallurgy 2018, 175, 359-366. [CrossRef]

28. Regel-Rosocka, M.; Wisniewski, M.; Borowiak-Resterna, A.; Cieszynska, A.; Sastre, A.M. Selective extraction of palladium(II) from hydrochloric acid solutions with pyridine carboxamides and ACORGA ${ }^{\circledR}$ CLX50. Sep. Purif. Technol. 2007, 53, 337-341. [CrossRef]

29. Wiecka, Z.; Rzelewska-Piekut, M.; Wojciechowska, I.; Wieszczycka, K.; Regel-Rosocka, M. Recovery of Palladium(II) and Platinum(IV) in Novel Extraction Systems. Materials 2021, 14, 285. [CrossRef] [PubMed]

30. Rane, M.V. PGM ore processing: LIX reagents for palladium extraction \& platinum stripping from Alamine $336 \mathrm{using} \mathrm{NaOH-NaCl}$. Miner. Eng. 2019, 138, 119-124. [CrossRef]

31. Truong, H.T.; Lee, M.S.; Senanayake, G. Separation of $\mathrm{Pt}(\mathrm{IV}), \mathrm{Rh}(\mathrm{III})$ and Fe(III) in acid chloride leach solutions of glass scraps by solvent extraction with various extractants. Hydrometallurgy 2018, 175, 232-239. [CrossRef]

32. Grad, O.A.; Ciopec, M.; Negrea, A.; Duteanu, N.; Negrea, P.; Vodă, R. Evaluation of performance of functionalized amberlite XAD7 with dibenzo-18-crown ether-6 for palladium recovery. Materials 2021, 14, 1003. [CrossRef] [PubMed]

33. Alguacil, F.J.; Cobo, A. Solvent extraction with LIX 973N for selective separation of copper and nickel. J. Chem. Technol. Biotechnol. 1999, 74, 467-471. [CrossRef]

34. Dziwinski, E.J.; Szymanowski, J. Composition of copper extractant LIX 54-100. Solv. Ext. Ion Exch. 1996, 14, 219-226. [CrossRef]

35. Xie, F.; Lu, D.; Yang, H.; Dreisinger, D. Solvent extraction of silver and gold from alkaline cyanide solution with LIX 7950. Miner. Process. Extr. Metal. Rev. 2014, 35, 229-238. [CrossRef]

36. Radzyminska-Lenarcik, E.; Pyszka, I.; Ulewicz, M. Separation of $\mathrm{Zn}(\mathrm{II}), \mathrm{Cr}(\mathrm{III})$, and Ni(II) ions using the polymer inclusion membranes containing acetylacetone derivative as the carrier. Membranes 2020, 10, 88. [CrossRef] [PubMed]

37. Pyszka, I.; Radzyminska-Lenarcik, E. New polymer inclusion membranes in the separation of nonferrous metal ion from aqueous solutions. Membranes 2020, 10, 385. [CrossRef]

38. Takeuchi, T.; Böttcher, A.; Quezada, C.M.; Meade, T.J.; Gray, H.B. Inhibition of thermolysin and human-thrombin by cobalt(III) Schiff base complexes. Bioorg. Med. Chem. 1999, 7, 815-819. [CrossRef]

39. Bernardis, F.L.; Grant, R.A.; Sherrington, D.C. A review of methods of separation of the platinum-group metals through their chloro-complexes. React. Funct. Polym. 2005, 65, 205-217. [CrossRef]

40. Pirogov, A.V.; Havel, J. Determination of platinum, palladium, osmium, iridium, rhodium and gold as chloro complexes by capillary zone electrophoresis. J. Chromatogr. A 1997, 772, 347-355. [CrossRef]

41. Lee, J.Y.; Kumar, R.; Kim, J.S.; Park, H.K.; Yoon, Y.S. Liquid-liquid extraction/separation of platinum (IV) and rhodium (III) from acidic chloride solutions using tri-iso-octylamine. J. Hazard. Mater. 2009, 168, 424-429. [CrossRef] [PubMed]

42. Swain, B.; Jeong, J.; Kim, S.; Lee, J. Separation of platinum and palladium from chloride solution by solvent extraction using Alamine 300. Hydrometallurgy 2010, 104, 1-7. [CrossRef]

43. Zhang, A.; Wanyan, G.; Kumagai, M. Association behavior of 4-acylpyrazolone derivative and tertiary amine of high molecular weight in antagonistic synergistic extraction of palladium. J. Solut. Chem. 2004, 33, 1017-1028. [CrossRef]

44. Marcus, Y. The properties of organic liquids that are relevant to their use as solvating solvents. Chem. Soc. Rev. 1993, 22, 409. [CrossRef]

45. Rydberg, J.; Cox, M.; Musakis, C.; Chopin, G.R. Principles and Practices of Solvent Extraction, 2nd ed.; M. Dekker Inc.: New York, NY, USA, 2004.

46. Gutmann, V. Empirical parameters for donor and acceptor properties of solvents. Electrochim. Acta 1976, 21, 661-670. [CrossRef] 